\title{
HUBUNGAN ANTARA INTENSITAS KOMUNIKASI INTERPERSONAL DENGAN AGRESIVITAS
}

\author{
Rahmat Fitrah Tuasikal \\ Universitas Pattimura
}

\begin{abstract}
The research is aimed to discover relation between the intencity of interpersonal canmunication and aggressiveness. Subjek for thi research is student fion Psychology of Education and Guidance Program, FKIP UNP.ATTI, with amount of research subjek consist of 86 people.

To discover relation between intencity of interpersonal communication with aggressiveness, hence [in] using correlation data analysis of product moment. Result of data analysis show intencity of intepersonal communication and aggressiveness have negative correlation and very signifkan ( $x y=-0,460$ and $p<0,01$ ).

Effective contribution of intencity of interpersonal cornmunication equal to $21,1 \%$ to aggressiveness, the rest equal to $78,9 \%$ is other factor that have an effect on in this research, even internal factors and also eksternal factors.
\end{abstract}

Keyword : intensity Communications of interpersonal, Aggressiveness

Indonesia merupakan negara yang menjunjung tinggi asas persatuan dan kesatuan sebagaimana terdapat dalam sila ketiga Pancasila yang juga kemudian lebih dijelaskan lagi dalam pembukaan UndangUndang Dasar Negara Republik Indonesia tahun 1945. Asas persatuan dan kesatuan ini penting karena bangsa Indonesia terbagi dalam berbagai macam suku, bahasa dan agama. Secara geografis Indonesia terletak di antara dua benua dan dua samudra. Di satu sisi hal ini merupakan suatu kebanggaan dan keuntungan tersendiri bagi bangsa Indonesia karena memiliki keanekaragaman budaya dan hasii alam maupun posisi siiang yang menguntungkan. Namun di sisi iain tidak dapat dipungkiri bahwa keadaan tersebut juga menjadi sebuah kelemahan. Akibat dari berbagai macam perbedaan yang ada justru berpotensi menjadi sebuah pertentangan bagi bangsa sendiri.

Bangsa Indonesia sejak tahun 1997 , mulai menampakkan sebuah gejoiak yang mengagetkan, yang belum pernah terjadi sebelumnya. Kondisi masyarakat terlihat sangat memprihatinkan. Gejolak ini dimulai dengan krisis moneter yang melanda Indonesia tersebut kemudian diikuti dengan meningkatnya kasus-kasus agresivitas (dalam bentuk kerusuhan) yang terjadi d kota-kota besar maupun kecil pada tahun 1998 antara lain Jakarta, Soio, Bondowoso, Ambon, Sambas dan Sampit yang menelan koban tidak hanya materi tapi juga jiwa manusia dalam jumlah yang tidak dapat dikatakan sedikit. Adanya kasus-kasus agresivitas menyebabkan masyarakat menjadi resah dan iabil. Di Provinsi Maluku terjadi juga konflik sosial yang berlangsung dari tahun 1999 sampai dengan 2003.

$\mathrm{Hal}$ yang sama juga terlihat pada mahasiswa dan peiajar yang sering melakukan tawuran/perkelahian dalam rangka membela kepentingan dirinya sendiri maupun kelompoknya, yang sebabnya kadang merupakan hal yang sangat sepele atau mungkin karena ada kesalahpahaman 
maupun tindakan lain yang disalahartikan oleh pihak lain. Kasus yang terjadi pada mahasiswa antara lain seperti perkelahian yang disebabkan ada mahasiswa yang dianggap tidak sopan karena berjalan tanpa menghiraukan mahasiswa lain. Di samping itu, ada dua kelompok mahasiswa d mana terjadi kesalahpahaman dalam berita yang di sampaikan, sehingga berakhir dengan ketegangan yang memuncak antara kedua kelompok tersebut dan terjadi perkelahian.

Apabila komunikasi yang dilakukan antar individu mengalami hambatan atau gangguan, maka itu dapat membuat individuindividu pelaku komunikasi menjadi frustrasi. Frustrasi yang dialami individu tersebut kemudian dapat diekspresikan dengan tindakan-tindakan agresivitas.

Dengan demikian permasalahan penelitian dapat dirumuskan sebagai berikut : benarkah terdapat hubungan negatif antara intensitas komunikasi interpersonal dengan agresivitas?

\section{DASARTEORI}

\section{Agresivitas}

Secara umum, agresi merupakan segala bentuk perilaku yang bertujuan untuk. menyakiti orang lain baik secara fisik maupun psikis (Berkowitz, 1993). Senada dengan pandangan di atas, Brigham (1991) mengatakan bahwa agresivitas adalah tingkah laku yang bertujuan untuk menyakiti orang yang tidak ingin disakiti, baik secara fisik maupun psikologis. Sears dan kawankawan (1994) mengemukakan bahwa agresi adalah suatu tindakan yang melukai orang lain dan memang dimaksudkan untuk itu.

Hal senada juga disampaikan deh Baron dan Byme (1994) bahwa perilaku agresif adalah perilaku individu yang bertujuan untuk melukai atau mencelakakan individu lain yang tidak menginginkan datangnya tingkah laku terse but.

Lebih lanjut Baron dan Byrne (Koeswara, 1988) merumuskan empat faktor yang mendukung definisi di atas yaitu :

1. Individu yang menjadi pelaku dan individu yang menjadi korban.

2. Tingkah laku individu pelaku.
3. Tujuan untuk melukai atau mencelakakan (termasuk membunuh atau mematikan).

4. Ketidakinginan korban untuk menerima perilaku pelaku.

Berbeda dengan beberapa pengertian di atas Moore dan Fine (Koeswara, 1988) menjelaskan agresi sebagai tingkah laku kekerasan secara fisik. ataupun secara verbal terhadap individu lain atau terhadap objek-objek. Serupa dengan pengertian di atas, Herbert (Praditya, 1999) mengatakan bahwa agresi adalah bentuk tingkah laku yang tidak dapat diterima secara sosial, yang mungkin menyebabkan luka fisik atau psikis kepada orang lain, atau merusak benda-benda. Dari dua pendapat ini tertihat bahwa perilaku agresi tidak hanya dilakukan terhadap makhluk hidup, tetapi juga terhadap benda-benda atau objek lainnya seperti benda mati.

Dari beberapa pengertian yang dikemukakan di atas dapat disimpulkan bahwa agresivitas adalah tingkah laku manusia yang dilakukan dengan tujuan untuk menyakiti manusia lain ataupun terhadap objek benda, baik itu secara fisik maupun secara non ffik.

Dalam penelitian in aspek-aspek agresi di ambil dari ragam agresi sebagaimana yang diungkapkan Buss dan Perry (1992) karena menurut penulis pendapat ini lebih komprehensif dibandingkan yang lainnya.

Buss dan Perry (1992) mengatakan bahwa ada empat macam agresi, yaitu:

1. Agresi fisik adalah agresi yang dilakukan untuk melukai orang lain secara fisik. Hal ini termasuk memukul, menendang, menusuk, membakar, dan sebagainya.

2. Agresi verbal adalah agresi yang dilakukan untuk melukai orang lain secara verbal. Bila seorang mengumpat, membentak, berdebat, mengejek, dan sebagainya, orang itu dapat dikatakan sedang melakukan agresi verbal.

3. Kemarahan hanya berupa perasaan dan tidak mempunyai tujuan apapun. Contoh seseorang dapat dikatakan marah apabila apabila dia sedang merasa frustrasi atau tersinggung 
4. Kebencian adalah sikap yang negatif terhadap orang lain karena penilaian sendiri yang negatif. Contohnya adalah seseorang curiga kepada orang lain karena orang lain tersebut baik dan lain sebagainya.

Banyak faktor yang mempengaruhi agresivitas, salah satunya adalah intensitas komunikasi interpersonal. Baron dan Byrne (1994) mengelompokkan agresi menjadi tiga pendekatan dalam menerangkan penyebab dasar perilaku agresi, yaitu biologis, faktor eksternal, dan belajar. Komunikasi interpersonal merupakan salah satu bagian dari faktor belajar.

\section{Intensitas Komunikasi Interpersonal}

Fishbein dan Ajzen (1975) mengartikan intensitas adalah besarnya usaha individu dalam melakukan suatu tindakan.

Lebih lanjut komunikasi diartikan sebagai penyampaian atau penerimaan sinyal/pesan oleh organisme. Dirumuskan dalam teori komunikasi bahwa komunikasi adalah proses yang dilakukan suatu sistem untuk mempengaruhi sistem yang lain melalui pengaturan sinyal-sinyal yang disampaikan (Rakhmat, 1998). Praktiko (dalam Santhoso, 1996) berpendapal bahwa komunikasi merupakan suatu kegiatan atau usaha manusia untuk menyampaikan apa yang menjadi perkiran dan perasaannya, harapan atau pengalamannya pada orang lain.

Menurut DeVito (1997) komunikasi interpersonal merupakan penginiman pesanpesan dari seorang dan diterima oleh orang lain, atau sekelompok orang dengan efek dan umpan baliklangsung.

Keltner (Dharmawan, 1993) mengatakan bahwa dalam komunikasi interpersonal, pembicaraan antara kedua pihak berlangsung akrab, berusaha saling memahami, terjadi tanya jawab, sehingga terdapat saling pengertian, disertai segala macam lambang yang melengkapi kata demi terdapatnya pengertian yang serasi diantara kedua pihak yang terlibat.

Dalam komunikasi interpersonal faktor situasi memegang peran yang cukup penting bagi komunikator, karena komunikator dapat mengetahui diri komunikan selengkap-lengkapnya, baik itu nama, pekerjaan, agama, suku, pengalaman ${ }_{k}$ cita-cita, dan lain sebagainya.

Menurut Pareek (Dharmawan, 1993), umpan balik interpersonal paling sedikit melibatkan dua orang, satu yang memberikan umpan balik dan yang lain menerimanya. Tujuan utama umpan balik adalah untuk membantu seseorang meningkatkan efektivitas pribadi dan efektivitas antar pribadinya. Umpan balik interpersonal juga membantu memperbaiki komunikasi antara dua orang yang terlibat dalam umpan balik melalui pembentukan budaya keterbukaan dan membina kepercayaan. Umpan balik yang terusmenerus akan membantu membentuk norma-norma keterbukaan. Akhirnya dalam komunikasi interpersonal umpan balik yang efektif akan membantu meningkatkan otonomi orang yang menerima umpan balik itu, karena umpan balik seperti itu tidak memberikan ketentuan-ketentuan apapun, tetapi membantu orang itu melalui informasi untuk mendapatkan pilihan yang lebih luas guna menambah efektivitasnya

Lebih lanjut Pareek (Dharmawan, 1993) menjelaskan bahwa umpan balik terutama membantu komunikan untuk memproses data perilaku yang telah diterima dari orang lain berupa tanggapan dan perasaan yang telah dikomunikasikan orang kepadanya tentang pengaruh perilaku terhadap dirinya. Hal ini membantu untuk menyadari diri sendiri dan perilakunya. Mendapatkan informasi tentang bagaimana periłakunya ditanggapi dan dampaknya terhadap orang lain, menambah kepekaan dalam menangkap isyarat-isyarat dari lingkungan untuk menunjukkan tanggapan dan perasaan orang tentang perilakunya.

Di sini terlihat bahwa umpan balik memegang peran yang cukup penting dalam sebuah komunikasi interpersonal karena berfungsi sebagai pemerkaya dan pemerkuat komunikator, sehingga harapan yang timbul dalam proses komunikasi terse but dapat terpenuhi.

Dari penjelasan di atas dapat $d \mathfrak{d}$ 
simpulkan bahwa intensitas komunikasi interpersonal adalah besarnya usaha individu dalam menyampaikan informasi, sinyal, atau pesan kepada individu lain dengan mendapat umpan balik yang langsung dari individu yang lain tersebut sehingga terjadi hubungan yang timbal balik antara kedua individu tersebut.

Menurut Sukanto dan Handoko (Dharmawan, 1993) komunikasi interpersonal akan memberikan hasil yang baik apabila terdapat kepercayaan antara sesama pihak yang terlibat dalam proses komunikasi. Ketidakpercayaan dan kecurigaan kepada salah sału pihak dapat menyebabkan salah satu pihak bersifat def ensif dan mengurangi frekuaensi ekspresi yang terbuka.

Komunikasi interpersonal menuntut sikap terbuka atau open mindedness. Sikap terbuka ini sangat besar pengaruhnya dalam menumbuhkan komunikasi interpersorial yang ef ektif (Rakhmat, 1998).

Lebih rinci Devito (1997) mengemukakan bahwa efektifitas komunikasi interpersonal ditandai oleh:

1. Keterbukaan. Kualitas keterbukaan komunikasi interpersonal paling sedikit terdiri dari dua aspek yaitu aspek keinginan untuk terbuka bagi setiap orang yang berinteraksi dengan orang lain. Keinginan untuk terbuka ini dimaksudkan agar diri masing-masing tidak tertutup dalam menerima informasi dan berkeinginan untuk menyampaikan informasi dari dirinya, bahkan juga informasi mengenai dirinya kalau dipandang relevan dalam rangka pembicaraan interpersonal dengan lawan bicaranya. Aspek lainnya adalah keinginan untuk menanggapi secara jujur semua stimuli yang datang. Dalam keterbukaan ini sudah sepantasnya apabila masing-masing pihak bereaksi secara terbuka terhadap apa yang dikatakan.

2. Empati. Empati yang dimaksudkan untuk merasakan seperti yang dirasakan orang lain, suatu perasaan bersama perasaan orang lain, yaitu mencoba merasakan dalam cara yang sama dengan perasaan orang lain.

3. Dukungan. Dukungan ini ada kalanya terucapkan dan ada kalanya tidak terucapkan. Dukungan yang tidak terucapkan tidaklah mempunyai nilai yang negatif, melainkan dapat merupakan aspek positif dari komunikasi. Gerakan-gerakan seperti anggukan kepala, kerdipan mata, senyum, atau tepukan tangan merupakan dukungan yang tidak terucapkan

4. Kepositifan. Kualitas Kepositifan dalam komunikasi interpersonal paling sedikit mempunyai tiga aspek, yaitu (a). Komunikasi interpersonal akan berhasil apabila terdapat perhatian yang positif terhadap diri seseorang; (b). Komunikasi interpersonal akan terpelihara baik apabila suatu perasaan positif terhadap orang lain itu dikomunikasikan. Hal ini aken membuat orang lain merasa lebih baik dan mempunyai keberanian untuk lebih berpartisipasi pada setiap kesempatan; dan (c) suatu perasaan positif dalam situasi komunikasi interpersonal sangat bermanfaat untuk mengefektifkan kerjasama.

5. Kesamaan. Komunikasi interpersonal akan lebih berhasil apabila orang-orang yang berkomunikasi itu dalam suasana kesamaan, karena masing-masing pihak yang berkomunikasi merasa dihargai dan dihormati sebagai manusia yang mempunyai sesuatu yang penting untuk dikontribusikan kepada sesamanya.

Liliweri (1991) mengemukakan ciriciri komunikasi interpersonal sebagai berikut:

a. Komunikasi interpersonal melibatkan d dalamnya perilaku verbal dan non verbal. Apabila diperhatikan dengan sungguhsungguh maka setiap hari sebenamya setiap orang dalam komunikasi interpersonal telah melaksanakan pengiriman pesan-pesan yang bersifat verbal maupun non verbal. Komunikasi interpersonal ini biasanya dilangsungkan dengan tatap muka secara langsung sehingga aksi dan reaksi verbal maupun non verbal terdengar dan terlihat. Tandatanda verbal diwakili dalam penyebutan 
kata-kata, baik lisan maupun tertulis, sedangkan tanda-tanda non verbal terlihat dalam ekspresi wajah dan gerak tubuh, misalnya gerakan tangan.

Komunikasi interpersonal dalam memanfaatkan tanda-tanda informasi verbal maupun non verbal sebenarnya sangat memperhatikan isi dan hubungannya dengan suatu pesan. Unsur isi terdiri dari apa yang dikatakan dan diperbuat, sedangkan unsur hubungan terdiri atas bagaimana sesuatu itu dikatakan dan diperbuat.

b. Komunikasi interpersonal melibatkan perilaku yang spontan, scripted, dan contrived. Manusia dapat mengatakan apa saja yang ada dalam benaknya, kemudian mewujudkannya baik dalam perilaku yang disebut spontan, scripted, dan conirived. Cara yang dipilihnya juga tergantung pada tujuan hubungan of antara manusia, sehingga perilaku itu menggambarkan harapan-harapannya akan tercapai atau tidak. Perilaku spontan dalam komunikasi interpersonal dilakukan secara tiba-tiba, untuk menjawab sesuatu rangsangan dari luar tanpa terpikirkan lebih dahulu. Perilaku spontan yang dilakukan merupakan refleks dari hati seseorang. Perilaku scripted merupakan reaksi terhadap pesan yang diterima apabila pada taraf yang terus menerus membangkitkan kebiasaan untuk belajar, dan akhimya perilaku ini dilakukan karena dorongan faktor kebiasaan. Perilaku contrived merupakan perilaku yang sebagian besar didasarkan pada pertimbangan kognitif. Dalam perilaku contrived, seseorang berperilaku karena mempunyal pendapat atau percaya bahwa apa yang dilakukan benar-benar rasional sesuai dengan pikiran, pendapat, dan kepercayaan serta keyakinannya.

c. Komunikasi interpersonal sebagai suatu proses yang berkembang. Komunikasi interpersonal merupakan suatu proses yang berkembang, menunjukkan bahwa komunikasi interpersonal sebenamya tidaklah statis melainkan dinamis. Pada saat terlibat dalam proses komunikasi interpersonal, manusia tidak sadar bahwa keberhasilan komunikasi disebabkan masing-masing pihak berhasil mempertukarkan pengalamannya, memberitahukan suatu informasi, menukarkan ide-ide dan pengetahuannya, dan pada saat ilu pula masing-masing pihak secara bergantian mendengarkan dengan penuh perhatian. Pertukaran pengalaman seperti ini merupakan pernerkayaan komunikasi interpersonal untuk lebih mendekatklan peserta, saling mengerti dan saling melengkapi, meningkatkan keterkaitan psikologis antara komunikator dan komunikan, menumbuhkan saling percaya, menumbuhkan kesamaan, untuk kemudian sama-sama dalam bertindak.

d. Komunikasi interpersonal harus menghasilkan umpan balik, mempunyai interaksi, dan koherensi. Komunikasi interpersonal harus ditandai dengan adanya umpan balik. Apabila seseorang berbicara dengan orang lain dan yang diharapkan adalah jawabannya sehingga dapat diketahui pikiran, perasaan, dan meiaksanakan apa yang dimaksudkan. Apabila harapan-harapan it terpenuhi, maka dapat disimpulkan bahwa komunikasi interpersonal telah berhasil karena umpan baliknya membuat kedua belah pihak saling mengerti. Um pan balik mengacu pada respon verbal maupun non verbal dari seorang komunikan maupun komunikatorsecara bergantian. Umpan balik saja tidaklah cukup, bahkan komunikasi interpersonal juga melibatkan interaksi di antara peserta komunikasi. Umpan balik tidak mungkin ada apabila tidak terdapat interaksi dan tindakanyang menyertainya.

Adanya interaksi menunjukkan bahwa komunikasi interpersonal harus menghasilkan suatu pengaruh tertentu. Interaksi dalam komunikasi interpersonal mengandalkan suatu perubahan sikap, pendapat dan pikiran, perasaan dan minat maupun tindakan tertentu. Selain umpan balik dan interaksi, hasil 
komunikasi interpersonal adalah koherensi. Koherensi, yaitu adanya hubungan yang terjalin antara pesanpesan verbal maupun non verbal yang terungkap sebelumnya dengan yang banu saja diungkapakan. Semua pihak dalam komunikasi interpersonal harus mengetahui alur, urutan cara berfikir, perasaan maupun tindakan pada waktu sedang berkomunikasi.

e. Komunikasi interpersonal biasanya diatur dengan tata aturan yang bersifat intrinsik dan ekstrinsik. Tata aturan intrinsik adalah suatu standar dari perilaku yang dikembangkan oleh seseorang sebagai petunjuk bagaimana melakukan komunikasi. Tata aturan intrinsik disepakati di antara peserta komunikasi interpersonal untuk meneruskan atau menghentikar tematema pembicaraan, perilaku verbal dan non verbal. Tata aturan ekstrinsik adalah satu standar yang timbul karena adanya pengaruh pihak ketiga atau pengaruh situasi dan kondisi, sehingga komunikasi interpersonal harus diperbaiki atau dihentikan.

f. Komunikasi interpersonal menunjukan adanya suatu tindakan. Komunikasi interpersonal menghendakli kedua pihak harus sama-sama mempunyai kegiatan, aksi, satu tindakan yang nyata dan diatur dengan suatu taktik dan strategi demi tercapainya tujuan komunikasi. $\mathrm{Hal}$ ini berarti bahwa komunikasi interpersonal tidak memerlukan perhatian hanya pada sebab datangnya suatu pesan kepada akibat pesan itu, namun lebih dari itu harus memperhatikan seluruh proses komunikasi.

9. Komunikasi interpersonal merupakan persuasi antar manusia. Persuasi tidak lain merupakan teknik untuk mempengaruhi manusia dengan memanfaatkan data dan fakta psikologis maupun sosial dari komunikan yang hendakdipengaruhi.

Komunikasi interpersonal melibatkan usaha yang bersifat persuasif, karena untuk mencapai sukses harus dikenal latar belakang psikologis dan sosiologis komunikan, dengan memanfaatkan pengetahuan, pendapat, perasaan serta kebiasaan seseorang, untuk kemudian pesan itu disesuaikan agar diterima komunikan.

\section{Intensitas Komunikasi Interpersonal dan Agresivitas \\ Dalam keseharian kehidupan,} sebagai mahluk sosial manusia membutuhkan interaksi dengan manusia lain untuk saling melengkapi dalam berbagai aspek, baik itu aspek fisik maupun psikologis. Agar interaksi tersebut dapat berjalan dengan baik, manusia membutuhkan komunikasi interpersonal (komunikasi timbal balik antar individu) yang menjadi jembatan penghubung antara manusia yang satu dengan yang lainnya.

Komunikasi yang menjadi penghubung tersebut sepatutnya berjalan dengan baik sehingga individu yang terlibat di dalamnya bisa merasa nyaman. Bila komunikasi interpersonal yang dilakukan dalam intensitas yang tinggi serta mendapatkan umpan balik yang positif maka kemungkinan besar akan terjadi sebuah hubungan yang saling menguntungkan antara kedua belah pihak. Sebaliknya apabila komunikasi interpersonal yang dilakukan tidak memiliki intensitas atau memiliki intensitas rendah serta tidak mendapat umpan balik seperti yang diharapkan maka timbul kemungkinan hubungan yang negatif antara kedua belah pihak. Bila terjadi hal seperti ini maka terlihat bahwa ada hambatan atau rintangan antar individu tersebut dalam melakukar komunikasi sehingga bisa menyebabkan timbulnnya rasa frustrasi pada individu akibat kegagalan berkomunikasi.

Dollard (Praditya, 1999) menyampaikan bahwa frustrasi, yang diakibatkan dari percobaan-percobaan yang tidak berhasil untuk memuaskan kebutuhan. akan mengakibatkan perilaku agresif. Sejalan dengan pendapat ini Berkowitz (1993) menyampaikan bahwa frustrasi dapat menjadi salah satu faktor untuk memicu agresi dalam diri individu. Menurut Baron dan Byrne (1994), ada dua kondisi timbulnya 
perilaku agresif, yaitu kondisi internal dan kondisi eksternal. Kondisi internal terdiri dari : (1). Kepribadian ; (2). Hubungan interpersonal yang salah satunya adalah komunikasi; (3). Kemampuan. Kondisi eksternal terdiri dari : (1) Frustrasi ; (2) Provokasi langsung yang bersifat verbal ataupun fisik yang mengenai kondisi pribadi; (3). Model yang kurang baik dalam lingkungan.

Dengan demikian apabila tingkat frustrasi seseorang meningkat maka perilaku agresinya akan meningkat pula. Seperti yang telah diuraikan sebelumnya bahwa agresi itu merupakan pengaruh faktor eksternal maupun sebuah proses belajar. Dengan demikian pada setiap individu memiliki potensi yang sama besar dalam mengekspresikan agresivitas.

Komunikasi interpersonal yang mendapat rintangan atau hambatan bisa menyebabkan komunikasl itu menjadi gagal dan membuat individu-individu pelaku komunikasi menjadi frustrasi. Frustrasi yang dialami individu tersebut kemudian dapat diekspresikan dengan tindakan-tindakan agresivitas.

Dengan uraian terse but dapat terlihat gambaran bahwa komunikasi interpersonal yang kurang intensif merupakan salah satu faktor penyebab agresivitas.

\section{Hipotesis}

Berdasarkan tinjauan pustaka yang telah diuraikan di atas, maka hipotesis yang dapat diajukan pad a penelitian ini adalah :

Ada hubungan negatif antara intensitas komunikasi interpersonal dengan agresivitas pada mahasiswa. Semakin tinggi intensitas komunikasi interpersonal maka tingkat agresivitas akan rendah, dan semakin rendah intensitas komunikasi interpersonal maka semakin tlnggl tingkat agresivitas

\section{METODE PENELITIAN}

\section{Populasi dan Sampel}

Populasi penelitian ini adalah mahasiswa Program Studi Psikologi Pendidikan dan Bimbingan Jurusan IImu Pendidikan, FKIP UNPATTI, dengan menggunakan sampel total dari populasi, dengan jumlah subyek penelitian terdiri dari 86 orang.

\section{Metode danAlat Pengumpulan Data}

Pengumpulan data dalam penelitian ini dilakukan dengan menggunakan skaia. Metode ini digunakan karena dalam pengungkapan variabel-variabel dalam penelitian ini, yaitu Intensitas komunikasi interpersonal dan agresivitas akan lebih mudah bila menggunakan skala.

1. Skala intensitas komunikasi interpersonal

Data intensitas komunikași interpersonal dalam penelitian ini diungkap dengan menggunakan skala intensitas komunikasi interpersonal yang disusun oleh Dharmawan (1993) dan dimodifikasi oleh penulis. Skala ini selanjutnya diberi judul Skala I. Penyusunan skala ini didasarkan pada pendapat dari DeVito (1997) dengan menggunakan aspek : keterbukaan, empati, dukungan, kepositifan, dan kesamaan. Jumlah aitem dari skala ini adalah 36 dengan 7 aitem keterbukaan, 5 aitem empati, 7 aitem dukungan, 10 aitem kepositifan, dan 7 aitem kesamaan.

2. Skala agresivitas

Data agresivitas dalam penelitian ini diungkap dengan menggunakan skala agresivitas yang disusun oleh Praditya (1999) dan dimodifikasi oleh penulis. Skala ini selanjutnya diberi judul Skala II. Penyusunan skala ini didasarkan pada pendapat dari Buss dan Perry (1992) dengan menggunakan aspek : agresi fisik, agresi verbal, kemarahan dan kebencian. Jumlah aitem dari skala ini adalah 35 dengan 8 altem agresi fisik, 9 aitem agresi verbal, 9 aitem kemarahan, dan 9 aitem kebencian.

\section{Metode Analisis Data}

Metode analisi statistik yang digunakan dalam penelitian int adalah korelasi product moment. Komputasi data dilakukan dengan menggunakan fasilitas komputerisasi SPSS 10.01 for Windows. 


\section{HASIL PENELITIAN}

\section{Pelaksanaan Penelitian}

Pengambilan data penelitian dilakukan di Kampus FKIP UNPATTI pada tanggal 3-4 November 2006

Prosedur yang dilakukan adalah subyek diberi satu ekesmplar angket yang berisi dua skala yaitu skala intensitas komunikasi interpersonal dan skala agresivitas. Setelah itu subyek mengisi kedua skala tersebut dan dikembalikan pada saat itu juga.

Dari 90 eksemplar skala yang dibagikan, diperoleh 86 eksmeplar skala yang dilsi dengan benar dan memenuhi syarat untuk dianalisis.

\section{Hasil UilAsumsi}

Sebelum ui hipotesis penelitian yang menggunakan teknik product momen terfebih dahulu dilakukan uj prasyarat, yaitu uji normalitas dan uji linearitas agar kesimpulan yang ditarik tidak menyimpang dari kebenaran yang seharusnya ditarik. (Hadi, 1992).

1. Uj Normalitas

Uji normalitas dengan menggunakan teknik One-Sample KosmogorovSmirnor Testdari program SPSS 10.1 for Windows, diperoleh hasil sebaran skor variabel intensitas komunikasi adalah normal (K-S $Z=0.5 ; p>0,05$ ) dan sebaran skor variabel agresivitas adalah normal $(K-S Z=0,855 ; p>0,05)$.

2. Uji Linieritas

Uji linieritas terhadap hubungan antara variabel intensitas komunikasl interpersonal dan agresivitas diperoleh nilai $F=0,927$ dengan $p>0,05$. Artinya hubungan kedua variabel linier.

\section{Has il Uji Analisis}

Hasil analisis menunjukan deskripsi data subjek penelitian yang berisi fungsifungsi statistik dasar, yang tersaji dalam tabel 6.

Tabel 1

Deskripsi Data Subjek Penelitian

\begin{tabular}{ccccccccc}
\hline \multirow{2}{*}{ Variabel } & \multicolumn{4}{c}{ Hipotetik } & \multicolumn{5}{c}{ Empirik } \\
\cline { 2 - 9 } & $X_{\min }$ & $X_{\max }$ & Mean & SD & $X$ min & $X$ max & Mean & SD \\
\hline $\begin{array}{c}\text { Intensitas } \\
\text { Komunikasi } \\
\text { Interpersonal }\end{array}$ & 36 & 180 & 72 & 24 & 113 & 166 & 142,15 & 11,04 \\
\hline Agresivitas & 35 & 175 & 70 & 23,33 & 62 & 125 & 86,02 & 15,96 \\
\hline
\end{tabular}

Peneliti memanfaatkan deskripsi data penelitian untuk mengetahui apakah tingkat intensitas komunikasi interpersonal dan agresivitas subyek termasuk tinggi atau rendah, yaitu dengan membuat kategori masing-masing variabel berdasarkan deskripsi data penelitian di atas. Kategori dibuat berdasarkan sebaran hipotetik, yaitu nilai maksimal dikurangi nilai minimal, sehingga diperoleh perkiraan besarnya deviasi standar hipotetik. Skor empiris yang berada 1,5 deviasi standar di atas mean hipotetik dikategorikan tinggi. Skor empiris yang berada 1,5 deviasi standar di bawah mean hipotetik dikategorikan rendah (Azwar, 1999).

Perhitungan pada intensitas komunikasi interpersonal diperoleh sebaran hipotetik $180 \quad 36=144$, selanjutnya didapat deviasi standar skor skala 144: $6=24$. Mean hipotetik adalah 72, maka batas kelompok tinggi adalah $72+1,5(24)=108$. Batas 
rendah adalah $72 \quad 1,5 \quad(24)=36$. Se telah mendapatkan batas kelompok tinggi dan rendah, maka subjek yang mendapat skor di bawah 36 dalam skala intensitas komunikasi interpersonal dapat dikatakan memiliki tingkat intensitas komunikasi interpersonal dalam taraf rendah. Sebalknya subjek yang memiliki skor di atas 108 dalam skata intensitas komunikasi interpersonal dapat dikatakan memiliki tingkat intensitas komunikasi interpersonal dalam taraf yang tinggi.

Dilihat dari rerata empirik yang diperoleh sebesar 142,15, maka lingkat intensitas komunikasi interpersonal subjek penelitian ini berada dalam kategori tinggi.

Perhitungan pada agresivitas diperoleh sebaran hipotetik $17535=140$, selanjutnya didapat deviasi standar skor skala $140: 6=23,33$. Mean hipotetik adalah 70 , maka batas kelompok tinggi adalah $70+$ $1,5(23,33)=104,995$. Batas rendah adalah $70 \quad 1,5 \quad(23,33)=37,005$. Setelah mendapatkan batas kelompok tinggi dan rendah, maka subjek yang mendapat skor di bawah 37,005 dalam skala agresivitas dapat dikatakan memiliki tingkat agresivitas dalam taraf rendah. Sebaliknya subjek yang memiliki skor di atas 104,995 dalam skala agresivitas dapat dikatakan memiliki tingkat agresivitas dalam taraf yang tinggi.

Dilihat dari rerata empirik yang diperoleh sebesar 86,02 , maka tingkat intensitas komunikasi interpersonal subjek penelitian ini berada dalam kategori sedang.

\section{Hasil Uj Hipotesis}

Analisis data yang dipergunakan untuk menguji hipotesis penelitian adalah dengan teknik korelasi Product Moment dari Pearson. Uj hipotesis tersebut dilakukan dengan bantuan seperangkat komputas dengan program SPSS 11.0 for Windows. Hasil analisis pruduct moment Pearson yang telah dilakukan diperoleh $r_{y g}=-0,460$ dengan $p<0,01$ yang artinya hipotesis yang diajukan diterima. Berarti ada hubungan negatif yang sangat signifikan antara intensitas komunikasi interpersonal dengan agresivitas.

\section{PEMBAHASAN}

Hasil penelitian ini mendukung hipotesis yang diajukan bahwa ada hubungan negatif antara intensitas komunikasi interpersonal dengan agresivitas. Hal ini berarti bahwa mahasiswa Prodi Psikologi Pendidikan dan Bimbingan FKIP UNPATTI yang tingkat intensitas komunikasi interpersonal tinggi memiliki tingkat agresivitas yang rendah.

Menurut Baron dan Byrne (1994) ada dua kondisi timbulnya perilaku agresif, yaitu kondisi internal dan kondisi eksternal. Kondisi internal terdiri dari: (1). Kepribadian; (2). Hubungan intnerpersonal yang salah satunya adalah komunikasi; (3). Kemampuan. Sementara kondisi ekstemal terdiri dari (1). Frustrasi; (2). Provokasi langsung yang bersifat verbal ataupun fisik yang mengenai kondisi pribadi; (3). Model yang kurang baik dalam lingkungan.

Dollard (Praditya, 1999) menyampaikan bahwa frustrasi, yang diakibatkan dari percobaan-percobaan yang tidak berhasil untuk memuaskan kebutuhan, akan mengakibatkan perilaku agresif. Sejalan dengan pendapat ini Berkowitz (1993) menyampaikan bahwa frustrasi dapat menjadi salah satu faktor untuk memicu agresi dalam diri individu. Apabila tingkat frustrasi seseorang meningkat maka perilaku agresinya akan meningkat pula.

Komunikasi interpersonal yang penuh rintangan atau hambatan menyebabkan komunikasi itu menjadi gagal dan membuat individu-individu pelaku komunikasi menjadi frustrasi. Frustrasi yang dialami individu tersebut kemudian dapat diekspresikan dengan tindakan-tindakan agresivitas.

Berkowitz (1993) mengatakan bahwa frustrasi menyebabkan sikap siaga untuk bertindak secara agresif karena kehadiran kemarahan (anger) yang disebabkan oleh frustrasi itu sendiri. Apakah individu bertindak secara agersif maupun tidak tergantung dari kehadiran isyarat agresif (aggressive cue) yang memicu kejadian aktual agresi tersebut. Jadi perilaku agresif mempunyai bermacam-macam 
penyebab, di mana frustrasi hanyalah salah satunya.

Sears dan kawan-kawan (1994) menambahkan bahwa meskipun frustrasi sering menimbulkan kemarahan, dalam kondisi tertentu hal tersebut tidak terjadi. Oleh karena itu, dapat ditarik kesimpulan bahwa peningkatan frustrasi tidak otomatis menimbulkan perilaku agresi, melainkan ada beberapa faktor lain yang dapat mencetusnya.

Hasil penelitian ini mendukung penelitian-penefitian serupa yang dilakukan sebelumnya oleh Hariyanti (Santhoso, 1996) maupun Santhoso (1996) yang menyatakan bahwa ada korelasi yang signifikan antara intensitas komurikasi remaja-orang tua dengan perilaku agresif remaja.

Dari hasil penelitian ini, tingkat intensitas komunikasi subjek penelitian berada dalam kategori tinggi (mean empirik = 142,15 ; mean hipotetik $=72$ ). Hal ini dapat dimakJumi karena di lingkungan Program Studi Psikologi Pendidikan dan Bimbingan terlihat adanya kedekatan antara mahasiswa dengan mahasiswa lainnya maupun antara mahasiswa dengan dosen. Hal lain yang memungkinkan tingkat komunikasi interpersonal subjek tinggi yaitu adanya suatu proses adaptasi dengan situasi kampus.

Tingkat agresivitas subjek penelitian berada dalam kategori sedang (mean empirik $=86,02$; mean hipotetik 70 ). Hal ini dimungkinkan karena adanya penanaman nilai moral dan agama dalam keluarga maupun tempat pendidikan secara relatif baik, sehingga dalam bertindak cenderung tidak melanggar norma-norma sosial, budaya dan agamanya.

Kontribusi intensitas komunikasi interpersonal terhadap agresivitas diketahui sebesar $0,211(21,1 \%)$. Hal ini menunjukkan bahwa intensitas komurikasi interpersonal seseorang memberikan sumbangan efektif sebesar $21,1 \%$ terhadap agresivitas yang ditunjukkan. Sisanya sebesar $78,9 \%$ adalah faktor lain yang turut berpengaruh namun tidakdiperhatikandalam penelitian ini. Faktor lain itu dimungkinkan berasal dari faktor internal lain maupun faktor eksternal.

\section{PENUTUP}

Hasil penelitian ini menunjukkan bahwa ada hubungan negatif yang sangat signifikan antara intensitas komurikasi interpersonal dengan agresivitas pada mahasiswa Program Studi Psikologi Pendidikan dan Bimbingan. Artinya mahasiswa yang memiliki tingkat intensitas komunikasi interpersonal tinggi menunjukkan tingkat agresivitasnya yang rendah.

Berkaitan dengan hasil penelitian ini, saran yang dianjurkan oleh penulis berdasarkan hasil penelitian yang diperoleh adalah:

1. Saran kepada kepada mahasiswa

Hasil penelitian ini diharapkan dapat memberikan informasi dan masukan bagi para mahasiswa untuk lebih dapat menjalin suatu hubungan komun|kasi interpersonal dalam intensitas yang baik sehingga dapat mencegah timbulnya agresivitasdikalangan mahasiswa.

2. Saran kepada pihak program studi Psikologi

Pihak program studi Psikologi selaku pendidik formal dapat lebih memberikan pendidikan yang bertema komurikasi yang baik secara teori maupun secara praktis yang kemudian diharapkan dapat dimanfaatkan oleh segenap keluarga besar FKIP UNPATTI untuk saling mendukung dalam berbagai kegiatan.

3. Saran kepada Pemerintah

Diharapkan akan lebih banyak diadakan program pembinaan masyarakat yang berkaitan dalam pembinaan komunikasi dalam rangka menurunkan tingkat agresivitas yang semakin meningkat dalam masyarakat indonesia.

4. Saran kepada peneliti selanjutnya

Bagi peneliti diharapkan untuk mempertimbangkan variabel-variabel lain yang berkaitan dengan masalah agresivitas seperti tempat tinggal atau daerah asal, adat istiadat maupun budaya, tingkat pendidikan, latar belakan keluarga dan lain sebagainya. 


\section{DAFTAR PUSTAKA}

Azwar, S. 1997. Reliabilitas dan validitas. Yogyakarta : Pustaka Pelajar.

1999. Penyusunan Skala Psikologis. Yogyakarta : Pustaka Pelajar.

Baron, R, A. \& Byrne, D. 1994. Social Psychology: Understanding Human Interaction. $7^{\text {th }}$ Edition. Boston: Allyn \& BAcon.

Berkowitz, L. 1993. Aggression: it's Causes, Consequences and Control. New York:McGrawHill, Inc.

Brighman, J, C. 1991. Social Psychology. New York: Harper Collin Publiser Inc.

Buss, A, H. \& Perry, M. 1992. The Agression Questionnaire. Journal of Personality \& Social Psychology Vol. 63. No.33. 452-459.

Dharmawan, A 1993. Hubungan Antara Komunikasi Interpersonal Dengan Keterlibatan Kerja Pada Tenaga Perawat Di RS. Bethesda. Skripsi. Tidak diterbitkan. Yogyakarta: Fakultas Psikologi UGM,

DeVito, J.1997. KomunikasiAntarManusia. Edisi kelima, Jakarta: Professional Book.

Fishbein, $M_{\text {s, }}$ and Ajzen, I. 1975. Belief, Attitude, Intention, and Behavior: An Introduction to Theory and Research. Reading. Massachussets: Addison-
Westey Publishing Co, Inc.

Hadi, S. 1992. Statistik 2 Yogyakarta: Andi Offset

1995. Metodologi Research 2. Yogyakarta :Andi Offset.

Koeswara, E. 1988. Agresi Manusia. Bandung: PT. Eresco.

Liliweri. 1991. Prespektif Teoritis Komunikasi. Antar Pribadi: Suatu Pendekatan Ke Arah Psikologi Sosial Komunikasi. Bandung: CitraAditya Bakti.

Praditya, D, L. 1999. Pengaruh Tayangan Adegan Kekerasan Yang Nyata Terhadap Agresivitas. Skripsi. Tidak diterbitkan. Yogyakarta: Fakultas Psikologi UGM.

Rakhmat, J. 1998. Psikologi Komunikasi. Edisi Revisi. Bandung: PT. Remaja Rosdakarya Offset.

Santhoso, F. H. 1996. Hubungan Antara Intensitas Komunikasi Remaja-Orang Tua Dengan kecenderungan Perilaku Agresif Remaja Di Kotamadia Yogyakarta. Laporan Penelitian. Tidak diterbitkan. Yogyakarta: Fakultas Psikologi UGM.

Sears, D. O. Freedman, J.L., Peplau, L.A. 1994. Psikologi Sosial. Edisi Kelima. Jilid 2. Jakarta: Erlangga.

Susanto, A S. 1970. Komunikasi Teori dan Praktek. (Jilid I). Bandung: Bina Cipta. 